\title{
Observation of a population of Egyptian Vultures Neophron percnopterus in Ramanagaram Hills, Karnataka, southern India
}

\section{Arockianathan Samson ${ }^{*}$ and Balasundaram Ramakarishnan}

Mammalogy and Forest Ecology wing, Department of Zoology and Wildlife Biology, Government Arts College, Udhagamandalam-643 002, The Nilgiris, Tamil Nadu, India

*Corresponding Author: kingvulture1786@gmail.com

http://dx.doi.org/10.4314/vulnew.v71i1.3

\section{Abstract}

The results of counts at two different regular Egyptian Vulture Neophron percnopterus feeding sites are presented for the Ramanagaram Hills Reserve Forest between 2013 and 2014 in Karnataka, southern India. The number of Egyptian Vultures recorded at feeding sites ranged from 2 to 19 individuals (mean $12.3 \pm 1.76$ s.e.). The attitude of local people towards vulture conservation was assessed and more than 90\% (90.82\%) of respondents had a favourable opinion of vultures. We highlight that educating livestock owners, farmers and veterinary personnel is essential to secure healthy food for vultures.

\section{Introduction}

Vultures perform a vital role in nature's sanitation process by eating meat from carcasses (Houston 1974). While feeding, vultures reduce the potential spread of diseases that could affect other animals and humans (Ogada et al. 2012a). Nine species of vultures are recorded in India (Ali \& Ripley 1987) and of these, six are found in southern India namely Egyptian Vulture Neophron percnopterus, Red-headed Vulture Sarcogyps calvus, White-rumped Vulture Gyps bengalensis, Longbilled Vulture Gyps indicus, Cinereous Vulture Aegypius monachus and Himalayan Vulture Gyps himalayensis (Srinivasulu \& Srinivasulu 1999, Sashikumar 2001, 
Subramanya 2001, Davidar \& Davidar 2002, Thejaswi 2004, Subramanya \& Naveen 2006, Davidar 2007, Umapathy et al. 2009, Ramakrishnan et al. 2010, 2012, Praveen et al. 2014, Ramakrishnan et al. 2014, Samson et al. 2014a.b, Samson et al. 2015, Samson et al. 2016 a.b).

Presently, 14 of the world's 23 (61\%) vulture species are threatened with extinction and the most rapid declines have occurred in the vulture-rich regions of Asia and Africa (Ogada et al. 2012b). The reasons for these population declines vary, but poisoning (both deliberate and accidental) or human persecution or both feature in the list of nearly every declining species. The most drastic decline of all in vulture populations occurred over the Indian subcontinent since the 1990s (Prakash 1999, Prakash \& Rahmani 1999, Virani et al. 2001, Prakash et al. 2003, Gilbert et al. 2004, Chhangani 2005). These declines and the critical conservation status of most vultures in India are largely due to the veterinary drug diclofenac, used on cattle, which has proved to be highly toxic to any vultures feeding on the carcass of a recently treated animal (Oaks et al. 2004, Green et al. 2004). Both Egyptian and Red-headed Vultures have declined in parallel to Gyps vultures in the Indian subcontinent, including Nepal (Cuthbert et al. 2006). These species are therefore also considered to be susceptible to diclofenac poisoning (Green et al. 2004, Cuthbert et al. 2006).

The Egyptian Vulture is a resident species of Ramanagaram Hills in Karnataka, southern India. It plays an important ecological role by removing municipal waste and animal carcasses. The breeding range of this species is very large and spreads over southern Europe, northwest Africa and some areas of near Asia and India (Cramp \& Simmons 1980). Egyptian Vultures normally feed on carrion and generally prefer forested habitats to human-dominated areas. Ali \& Ripley (1987) however, highlight that the Egyptian Vulture can persist near human habitation and that it forages in refuse dumps. It is therefore an opportunistic scavenger that uses a variety of food sources in its diet. The aim of the present study was to examine the population status and feeding behaviour of Egyptian Vultures and also to assess people's perception of Egyptian Vultures in the Ramanagaram Hills Reserve Forest, Karnataka, an area unrepresented for studies on this species. 


\section{Study area}

The Ramanagaram Hills are sparsely vegetated granite hills located to the southwest of Bangalore $\left(12^{\circ} 07-\right.$ $\left.12^{\circ} 58^{\prime} \mathrm{N} \quad 7^{\circ} 08^{\prime}-77^{\circ} 25^{\prime} \mathrm{E}\right)$ in Karnataka, India (Map 1). They extend for approximately $75 \mathrm{~km}$ and are approximately $25 \mathrm{~km}$ wide. The average elevation is $747 \mathrm{~m}$ (2450 feet) above sea level. The hills are home to a wide variety of flora and fauna and the forest-covered slopes are of significant ornithological importance, supporting over 150 species of birds including the endemic Yellowthroated Bulbul Pycnonotus xantholaemus and the critically endangered Long-billed Vulture; one of the few locations in south India where Long-billed Vultures nest (Subramanya \& Naveen 2006). Although the Hills of Ramanagaram form part of the Important Bird Area (IBA) network in India (Islam \& Rahmani 2004), they are threatened by quarrying and also plans to carve statues into the hills.

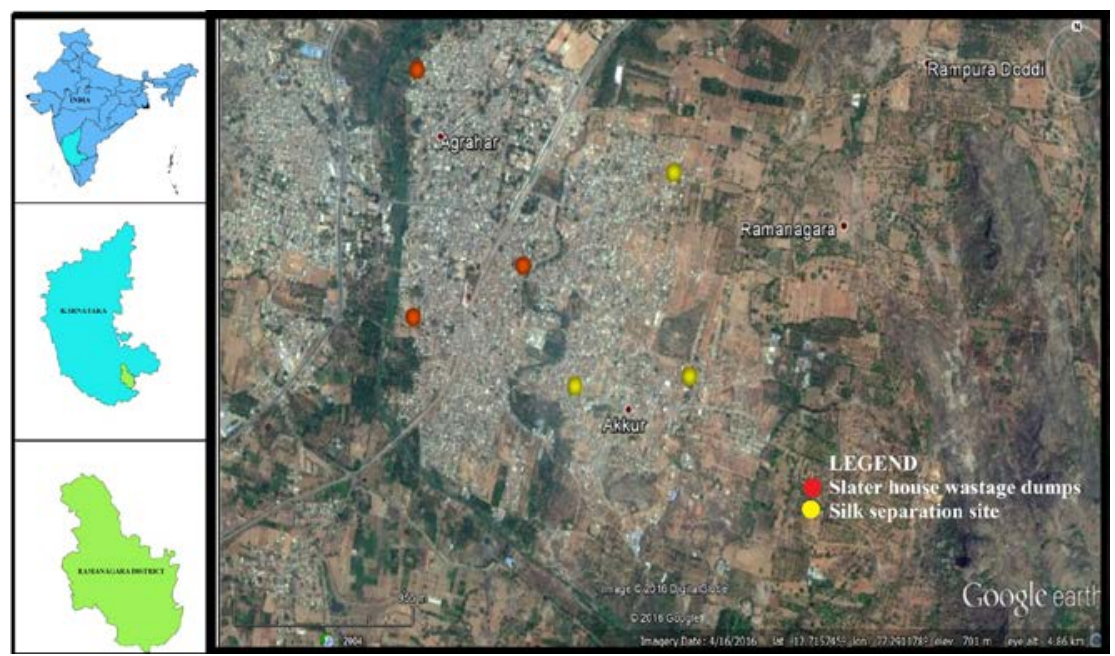

Map 1: Map showing the location of Ramangara and the study sites where Egyptian Vultures were counted. 


\section{Materials and methods}

The study was carried out from December 2013 to May 2014 in the Ramanagaram Hills Reserve Forest as well as surrounding areas of human habitation, which we considered to be favourable for sighting Egyptian Vultures. Counts of Egyptian Vultures, Black Kites Milvus migrans, Brahminy Kites Haliastur indus, House Crows Corvus splendens, Pond Herons Aredola grayii and Cattle Egrets Bubulcus ibis were done at twicemonthly intervals survey was completed at 8 am to 12 am in a day all feeding stations located at silk processing sites and slaughter houses (Map 1) in the Ramanagaram Hills (Purohit \& Saran 2013). Feeding behaviours were recorded using scan sampling and ad libitum methods (Altman 1974) and behaviour sampling rules (Martin and Bateson 1986), both of which are adequate for opportunistic records and were used throughout the observations whenever vultures were sighted during field visits. Birds were spotted with the naked eye and behaviours were observed through $10 \times 48$ binoculars from a distance of 80 to $100 \mathrm{~m}$.

A questionnaire was used to assess attitudes towards Egyptian
Vulture conservation among local people living within the forest fringes $(n=60)$ : local people $(n=16)$; livestock owners $(\mathrm{n}=30)$; silk processing site owners $(n=4)$; slaughterhouse owners $(n=4)$; local veterinarians $(n=2)$ and drug pharmacies $(n=4)$. The questionnaire recorded the age of the respondent, their religion, views of vulture conservation and the importance of vultures, carcass disposal methods, amount of livestock holdings, veterinary practices and diclofenac usage (Baral et al. 2005, Subadi 2007).

\section{Results}

Two counts per month were completed at the silk processing sites and the slaughterhouse waste dumps over the five months of the study. A total of 123 individual vultures were recorded across the 10 visits. Of the 123 birds, most birds (79) were adults (Table 1). The number of adult vultures sighted at a count ranged from 1 to 14 (7.9 \pm 1.26 s.e.), the number of sub-adults ranged from 1 to 4 (2.4 \pm 0.37 s.e.) and juveniles from 1 to 5 (2.75 \pm 0.45 s.e.). Overall counts of all age classes combined ranged from 2 to 19 (12.3 \pm 1.76 s.e). 
Table 1: Counts of Egyptian vultures at silk processing sites and slaughterhouses in the Ramanagaram Hills December 2013 to May 2014

\begin{tabular}{|c|c|c|c|c|c|}
\hline Months & $\begin{array}{c}\text { Count } \\
\text { No. }\end{array}$ & Adult & Sub-adult & Juveniles & Total \\
\hline \multirow{2}{*}{ December } & 1 & 6 & 2 & 4 & 12 \\
\cline { 2 - 6 } & 2 & 10 & 1 & 5 & 16 \\
\hline \multirow{3}{*}{ January } & 1 & 1 & 1 & 0 & 2 \\
\cline { 2 - 6 } & 2 & 5 & 2 & 2 & 9 \\
\hline \multirow{3}{*}{ March } & 1 & 10 & 4 & 3 & 17 \\
\cline { 2 - 6 } & 2 & 6 & 2 & 0 & 8 \\
\hline \multirow{3}{*}{ Mpril } & 1 & 13 & 4 & 2 & 19 \\
\cline { 2 - 6 } & 2 & 9 & 3 & 1 & 13 \\
\hline \multirow{2}{*}{$\begin{array}{c}\text { Total } \\
\text { (Mean } \pm \text { s.e.) }\end{array}$} & 1 & 5 & 0 & 3 & 8 \\
\cline { 2 - 6 } & 2 & 14 & 3 & 2 & 19 \\
\hline & 79 & 22 & 22 & 123 \\
$(7.9 \pm 1.26)$ & $(2.4 \pm 0.37)$ & $(2.75 \pm 0.45)$ & $(12.3 \pm 1.76)$ \\
\hline
\end{tabular}

\section{Feeding associations}

Two types of feeding were observed at silk separation sites: waste areas and feeding on worms and invertebrates. In total, six species of larger bird were recorded at silk separation sites. The most numerous birds at the silk separation sites were Brahminy Kites and Black Kites; Egyptian Vulture were the least numerous (Table 2).
At the silk separation sites, wastes are dumped into drainage areas and these wastes contain silk worms and larvae. These areas attract crows, herons, and egrets. More open and drying areas attract Black Kites, Brahminy Kites and Egyptian Vultures. In these areas the crows, herons and egrets are displaced by the kites and vultures, so they generally feed in the drainage wastage areas. 
Table 2: Counts of six species of larger bird at silk separation sites in the Ramanagaram Hills December 2013 to May 2014.

\begin{tabular}{|l|c|c|c|c|c|c|}
\hline Variables & $\begin{array}{l}\text { Black } \\
\text { Kite }\end{array}$ & $\begin{array}{l}\text { Brahminy } \\
\text { Kite }\end{array}$ & $\begin{array}{l}\text { House } \\
\text { Crow }\end{array}$ & $\begin{array}{l}\text { Pond } \\
\text { Heron }\end{array}$ & $\begin{array}{l}\text { Cattle } \\
\text { Egret }\end{array}$ & $\begin{array}{l}\text { Egyptian } \\
\text { Vulture }\end{array}$ \\
\hline Visits & 10 & 10 & 10 & 10 & 10 & 10 \\
\hline Total & 442 & 448 & 93 & 90 & 227 & 51 \\
\hline Min & 31 & 33 & 10 & 3 & 16 & 2 \\
\hline Max & 57 & 63 & 17 & 15 & 29 & 9 \\
\hline $\begin{array}{l}\text { Mean } \\
\text { (s.e.) }\end{array}$ & $44(2.41)$ & $49(3.19)$ & $13(1.02)$ & $9(1.35)$ & $23(1.48)$ & $5(0.67)$ \\
\hline
\end{tabular}

Conservation perspectives Egyptian Vulture conservation

Survey results showed that most people $(90.82 \%)$ have a favourable opinion of vultures and consider conservation of vultures good for nature because they keep the ecosystem clean. Most people (63\%, $\mathrm{n}=38$ ) considered that vultures are Nature's scavenger, although a significant proportion $(37 \%, n=22)$ considered them also to be hunters. Thirty cattle owners were interviewed and although most (79\%, $\mathrm{n}=23$ ) were illiterate, they answered that they did not know about diclofenac. The main disposal method for carcasses was not favourable for vultures. Most people (89\%, n=25) buried dead cattle and the remainder leave carcasses in an open area of the forest. The veterinarians interviewed were using the vulture-safe drug meloxicam for livestock. Although diclofenac is not available for veterinary use it is sold at pharmacies $(n=4)$ for human use. Several respondents indicated that in the Ramanagaram Hills, although most people are Hindu and therefore do not consume beef, there are a few Muslim communities and in these areas there are a few slaughterhouses and shops that sell beef.

\section{Discussion}

Vulture populations, especially Gyps species, across the Indian subcontinent have declined drastically from the 1990s (Prakash et al. 2003, Gilbert et al. 2004, Green et al. 2004). The Egyptian Vulture is a long-lived species, which is classified as endangered 
because of recent and rapid population declines in India and Nepal (Cuthbert et al. 2006). Hence, this study was conducted in the Ramanagaram Hills in order to make a first assessment of India's southern-most Egyptian Vulture population.

Diet and food intake is a central component of animal ecology, therefore knowledge of diet and food is key to understanding occurrence patterns, habitat selection and breeding productivity of species (Donázar \& Ceballos 1988, Litvaitis, 2000, Sonerud et al. 2001, Sonerud et al. 2002, Margalida \& Boudet 2003, Navarro et al. 2003, Sará \& Divittorio 2003, Zabala \& Zuberogoitia 2003, Zduniak \& Kuczynski 2003, Zduniak \& Antczak 2003). All vulture species feed on carcasses of small and large mammals, especially on the domestic animals in the vicinity of the Ramanagaram Hills. However, two additional congregations of feeding birds were studied here: dumps at slaughterhouses and worm feeding at silk processing sites. The silk cocoons contain pupae inside and these are separated manually at silk processing sites in the Ramanagaram hills; cocoons come from various places to be processed (10 times per month this work is carried out in
Ramanagaram Hills). The discarded pupae attract foraging birds and fresh pupae are especially attractive to Egyptian Vultures. Egyptian Vultures are most usually carrion feeders, in forest areas, but they are capable of thriving in areas of human habitation and at refuse dumps (Ali \& Ripley 1987).

Most people interviewed during the study were in favour of Egyptian Vulture conservation, but many respondents were illiterate and did not know about the impact of diclofenac on vulture populations. Despite this, the veterinary practices interviewed were favourable for vulture conservation in the study area. In Africa, Brandl et al. (1985) reported a negative correlation between human impact on the landscape and raptor diversity and density and it is clear that a positive conservation attitude is key to garnering local support for species conservation. Education campaigns, such as street theatres and distributing posters in local languages highlighting the importance of vultures and the threats they face should be conducted to inform the general public. Such programmes enhance the awareness of people to the wide range of values provided by vultures. Another important strategy is to 
educate livestock owners, farmers contaminated carcasses can cause a and veterinary personnel on the rapid population decline of vultures. negative effects of diclofenac and on Therefore, educating livestock the proper disposal of contaminated holders, farmers and veterinary carcasses. Green et al. (2004) found personnel will help to secure healthy that, based on demographic food for vultures. modelling, less than $1 \%$ of

\section{Acknowledgements}

The authors thank the Explorers Club and TEC 2015 Exploration Fund Grant for their support of this project. Our whole-hearted thanks go to Mr. Swamynathan Wildlife SOS Senior Biologist for giving the opportunity to work on this landscape for Sloth Bear Project. We thank our field assistant Mr. Vengadesh for taking lot of risk in collecting field data in the forests. An anonymous reviewer improved an earlier draft of this manuscript.

\section{References}

Ali, S. \& Ripley, S.R. 1987. Handbook of Birds of the birds of India and Pakistan, Oxford University press, New Delhi, Pp.76.

Altmann, J. 1974. Observational study of behavior: sampling methods. Behaviour 49:227- 267

Baral, N., R. Gautam \& B. Tamang .2005. Population status and breeding ecology of White-rumped Vulture Gyps bengalensis in Rampur Valley, Nepal. Forktail 21: 87-91.

Brandl, R., Utschick, H \& Schmidtke, K. 1985. Raptors and land-use systems in southern Africa. African Journal of Ecology 23: 11-20

Chhangani, A.K. 2005. Population ecology of Vultures in the western Rajasthan, India. Indian Forester 131: 1373-1382. 
Cramp, S. \& Simmons, K. (eds.) 1980. The birds of the western Palearctic. Vol. 2, Oxford University press, Oxford.

Cuthbert R., Green R.E., Ranade S., Saravanan S., Pain D.J., Prakash V. \& Cunningham A.A. 2006. Rapid population declines of Egyptian vulture (Neophron percnopterus) and red-headed vulture (Sarcogyps calvus) in India. Animal Conservation 9: 349-354.

Davidar, P. 2007. Indian White-backed Vultures Gyps bengalensis in the Sigur region of Tamil Nadu. Indian Birds 3 (4): 149

Davidar, E. R. C. \& Davidar, P. 2002. Possible causes for the decline of Oriental White-rumped vultures (Gyps bengalensis) in the Sigur region (Nilgiris, Tamil Nadu), India. Vulture News 47: 3-6.

Donazar, J.A \& Ceballos, O. 1988. Alimentacion y tasas reproductoras del alimoche (Neophron percnopterus) en Navarra. Ardeola 35: 3-14.

Gilbert, M., Virani, M. Z., Watson, R. T., Oaks, J. L., Benson, P. C., Khan, A. A., Ahmed, S., Chaudhry, M. J. I., Arshad, M., Mahmood, S. \& Shah, Q. A. (2004) The status and decline of vultures in the provinces of Punjab and Sind, Pakistan: a 2003 update. pp 311-326 in R. D. Chancellor and B.-U. Meyburg, eds. Raptors Worldwide. Berlin: World Working Group on Birds of Prey and Owls.

Green, R.E., I. Newton, S.Shultz, A.A. Cunningham, M. Gilbert, D.J. Pain \& V. Prakash (2004). Diclofenac poisoning as a cause of vulture population declines across the Indian subcontinent. Journal of Applied Ecology 41(5): 793-800

Houston, D. C. 1974. The role of griffon vultures (Gyps africanus) and (Gyps ruppellii) as scavengers. Journal of Zoology 172: 35-46. 
Islam, M.Z. \& A.R. Rahmani. 2004. Important Bird Areas in India: Priority areas for conservation. Mumbai, U.K. \& Mumbai: Bombay Natural History Society, BirdLife International, \& Oxford University Press.

Litvaitis, J. A. 2000. Investigating food habits of terrestrial vertebrates. In Boitani, L., Fuller, T. K. (Eds.) Research techniques in animal ecology. Controversies and consequences. 165-190. Columbia University Press, New York.

Margalida, A. \& Boudet, J. 2003: Dynamics and temporal variation in age structure at a communal roost of Egyptian vultures (Neophron percnopterus) in Northeastern Spain. Journal Raptor Research 37(3): 252256.

Martin, P \& Bateson, P. 1986. Measuring behaviour, an introductory guide.Cambridge: Cambridge University Press.

Navarro, J., Sánchez-zapata, J.A., Carrete, M. \& Botella, F. 2003. Diet of three sympatric owls in steppe habitats of eastern Kazakhstan. - Journal Raptor Research 37(3): 256-258.

Oaks, J.L., Gilbert, M., Virani, M.Z., Watson, R.T., Meteyer, C.U., Rideout, B.A., Shivaprasad, H.L., Ahmed, S., Chaudhry, M.J.I., Arshad, M., Mahmood, S., Ali, A. \& Khan, A.A. 2004. Diclofenac residues as the cause of vulture population decline in Pakistan. Nature 427: 630-633 
Ogada, D.L., Keesing, F \& Virani, M.Z. 2012a. Dropping dead: causes and consequences of vulture population declines worldwide. Annals of the New York Academy of Sciences 1249: 57-71.

Ogada, D.L., Torchin, M. E., Kinnaird, M. F. \& Ezenwa, V. O. 2012b. Effects of vulture declines on facultative scavengers and potential implications for mammalian disease transmission. Conservation Biology 26: 453-460.

Prakash, V. 1999. Status of Vulture in Keoladeo National Park, Bharatpur, Rajasthan, with special reference to population crash in Gyps species. J. Bombay Nat. Hist. Soc. 96: 365-368.

Prakash V, Rahmani AR (1999). Notes about the decline of Indian Vultures, with particular reference to Keoladeo National Park. Vulture's News 41:613.

Prakash, V., Pain, D. J., Cunningham A. A., Donald P. F., Prakash N., Verma A., Gargi R., Sivakumar S. \& Rahmani A. R. 2003. Catastrophic collapse of Indian White-backed (Gyps bengalensis) and Long-billed (Gyps indicus) Vulture populations. Biological Conservation 109: 381-390.

Praveen, J., Nameer, P.O., Karuthedathu, D., Ramaiah, C., Balakrishnan, B., Rao, K. M., Shurpali, S., Puttaswamaiah, R., \& Tavcar, I., 2014. On the vagrancy of the Himalayan Vulture Gyps himalayensis to southern India. Indian Birds 9 (1): 19-22

Purohit, A., and Saran, R.P., 2013: Population status and feeding behaviour of cinereous vulture (Aegypus monachus) dynamics and implications for the species conservation in and around Jodhpur. World Journal of Zoology 83: 312- 318. 
Ramakrishnan, B., Ramasubramanian, S., Saravanan, M \& Arivazhagan, C. 2010. Is Diclofenac the only culprit for declining population of Gyps Vultures in the Moyar Valley. Current Science 99 (12): 1645-1646.

Ramakrishnan, B., Ramasubramanian, S \& Samson, A. 2012. Occurrence of Red-headed vulture in Segur plateau, Tamil nadu. Current Science 102 (6): 832

Ramakrishnan, B. Kannan, G. Samson, A. Ramkumar, K. Ramasubramaniyan, S. (2014). Nesting of White-rumped vulture (Gyps bengalensis) in the Segur Plateau of The Nilgiri North Forest Division. Indian Forester 140(10): 1014-1018

Samson, A., Ramakrishanan,B., Kannan, G., Renuka,S \& Ramasubramanian,S. 2014a. Emerging threats for Egyptian vulture (Neophoran percnopterus ginginianus) in the Chamundi Hills Reserved Forest, Mysore, Karnataka. Newsletter for Birdwatchers 50(2): 16-17

Samson.A, Ramakrishnan.B, Renuka.S, Ravi.P, Ramasubramanian.S. 2014b. Bathing behavior and waterhole importance of white-rumped vulture conservation in the Segur Plateau, Tamil Nadu, Southern India. Journal of Applied Science and Research 2(5):92:99

Samson, A., Ramakrishanan,B., Veeramani, A \& Ravi, P. 2015. Occupation of Indian Giant Squirrel nests by White-rumped Vultures (Gyps bengalensis) in India. Podoces 10(2): 35-36

Samson A., Ramakrishnan B., Veeramani A. \& Ravi P. 2016a. Population Status and Habitat Preference of Vultures in Mudumalai Tiger Reserve, Tamil Nadu, Southern India. Podoces 11(1): 7-12. 
Samson A., Ramakrishnan B. \& Ravi P. 2016b. Wild boar predation on White-rumped vulture fledgling. Zoo’s Print XXXI (8):8

Sarà, M \& Di Vittorio, M. 2003. Factors influencing the distribution, abundance and nest-site selection of an endangered Egyptian vulture (Neophron percnopterus) population in Sicily. Animal Conservation 6:317-328.

Sashikumar , C. (2001) Vultures in Kerala. Newsletter for Birdwatchers 41:10-15

Sonerud, G. A., Hansen, H \& Smedshaug, C.A. 2002. Individual roosting strategies in a flock-living bird: movement and social cohesion of hooded crows (Corvus corone cornix) from pre-roost gatherings to roost sites. Behaviour Ecology Sociobiology 51: 309-318

Stotrabhashyam, S., Reddy, B., Satla, V \& Siddiqui, I. 2015. A breeding site record of Long-billed Vulture (Gyps indicus) (Aves: Accipitriformes: Accipitridae) from Bejjur Reserve Forest, Telangana, India. Journal of Threatened Taxa 7(1): 6800-6804

Srinivasulu, B. \& Srinivasulu, C. 1999. Status of vultures in Andhra Pradesh, India. Vulture News 40: 26-34

Subedi,P. 2007. Monitoring of Gyps species vulture in Nawalparasi district, Nepal. Banko Janakari. 18(2):35-43

Subramanya, S. 2001. Cinereous Vulture Aegypius monachus (Linn.), Family Accipitridae, in Karnataka. Journal of Bombay Natural History Society 98(2): 278. 
Subramanya, S. \& Naveein, O. C. 2006. Breeding of Long-billed Vulture (Gyps indicus) at Ramanagaram hills, Karnataka, India. Indian Birds 2 (2): 32-34.

Thejaswi, S .2004. A sight record of the Cinereous Vulture (Aegypius monachus) near Mysore, Karnataka, India. Newsletter for Ornithologists 1(5): 74

Umapathy, G., Hussain, S. \& Shivaji, S. 2009. Status and distribution on vultures in Andhra Pradesh, India. Forktail 25: 163.

Virani, M., Gilbert, M., Watson, R., Oaks, L., Benson, P., Khan, A.A., Baral, H.S \& Giri, J.B. 2001. Asian Vulture crisis project: field results from Pakistan and Nepal for the 2000-2001 field season; Edn. Katzner T, J. Parry Jones Eds. Reports from the workshop on Indian Gyps Vultures, $4^{\text {th }}$ Eurasian congress on raptors, Sevilla, Spain, September 2001. Seville, Spain: Estacion Biologica Donana Raptor Research Foundation. pp. 7-9.

Zabala, J. \& Zuberogoitia, I. 2003. Badger, Meles meles (Mustelidae, Carnivora), diet assessed through SEAT-analysis: a comparison and critique of different methods. - Folia Zoologica, 52(1): 23-30.

Zduniak, P \& Kuczynski, L. 2003. Breeding biology of the Hooded Crow (Corvus corone cornix) in Warta river valley (W Poland). Acta ornithologica 38 (2)

Zduniak, P. \& Antczak, M. 2003. Repeatability and within-clutch variation in egg dimensions in a Hooded Crow Corvus corone cornix population. Biological Letters 40(1): 37-42.

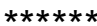

